\title{
Gëzim Hajdari: On a Poet and His Poetry of Exile
}

\author{
Alessandra Mattei \\ Faculty of Literature and Philosophical Studies, Department of Greek and Latin, Italian, \\ Scenic and Musical Studies, Sapienza University of Rome, Italy
}

Copyright $\mathrm{O} 2017$ by authors, all rights reserved. Authors agree that this article remains permanently open access under the terms of the Creative Commons Attribution License 4.0 International License

\begin{abstract}
Gëzim Hajdari's poetic subject is an exceptional case within the contemporary scenario. He has been spending in Italy his exile from Albania since 1992. Hajdari tries to express a semantic universe able to overpower effectively his readers' literary and cultural identities of reference, by adjusting the classical referents existing in several Mediterranean traditions. He has been always interested in the creation of a new epic, recalling - to overcome without abandoning it - his status of permanent dispatrio through the choice of genres and references, both alluded and manifest. The constant exile, which he and his work live in, is tied to the testimonial obligation of the horrors of dictatorship and the slaughter of an entire intellectual class; it also focuses attention on significant matters of the classical tragic and epic thought - especially the Greek one - and introduces it in the research of a widespread classical style, open to the literary traditions which are far from the Western ones. This aim, pursued by writing Delta del mio fiume [16], leads him to the editorial choices for Erranze series he runs, and to the latest decision to publish his first compendium in three languages.
\end{abstract}

Keywords Memory, Duty to the Grave, Poetry of Exile, Contemporary Epic, Poetry of Migration, Literature-word

\section{Introduction}

This article provides a brief description about the studies concerning the relationship between literature and exile, and aims at outlining a consistent picture of Gëzim Hajdari's poetic, literary and cultural work, starting from the critical opinions of his work's recreation and study, to reflect, more specifically, on some themes inferred by a text interrogation.

\subsection{Status Artists: Literature and Exile}

Before presenting the case study on Gëzim Hajdari, it may be useful to provide a brief description about the existing relationship between the condition of exile and his literary works. It is noteworthy to mention that this subject encompasses an immense and miscellaneous bibliography, due to its intricacy and the presence of several areas of interest (historical, linguistic, philosophical, literary, political and juridical).

Therefore, it is worthwhile to provide a brief overall summary, which does not specifically analyses all the heterogeneous items coming from the different literary results on exile: thus, I decided to take into a higher consideration the latest critiques on the general and literary developments of the set of ideas about this phenomenon.

The theme of exile, which had been distinguishing the educational path of various national literary identities as an actual topos since Romanticism, acquired a more pronounced centrality in the Twentieth century, when it started to embody one of the main transnational vehicle of intellectual, ideological, political and literary subject. [1]

Tightly bound to the crisis of democracy and modernity [2], exile lead to an existential drift and a high rate in the mobility of intellectuals and dissidents coming from the numerous totalitarian degenerations. As a matter of fact, the whole century may be seen as a long study where ideological actions and reactions defined it as the era of totalitarianisms. [3]

As a result, throughout the 1900s the complex dimension and a consequent establishment of widespread and recurring antidemocratic regimes - in the Eastern world of soviet derivation as much as in the different European and South American fascisms, and beyond the fall of those ideologies caused cruel political repressions against dissidents, especially intellectuals and writers. They would rather choose exile than dictatorship if they could save themselves from the recurring physical purge carried out by those regimes; and they would rather keep this condition, since they did not recognise themselves in the opacity of the transition towards democracy after the fall of those regimes [4: 353].

Along with the common postcolonial and migrant condition [2] and the more complex specific matter about the Jewish diaspora [5], the exile represents the main vehicle of contemporary ideological and intellectual flow [6]; it is also a premise to the global intelligibility, a witness and a neighbouring foundation, which gathers and creates a wide 
set of transnational democratic ideas.

This may be true according to history, to the origin of ideas, but it acquires some crucial peculiarities within the different literary perspectives embodied and accomplished by this phenomenon [7].

Undoubtedly, the testimonial value of literature is a source of a continuous relationship between the exiled intellectual and his or her reference community [4:350]. The latter does not always dovetails with the community in their homeland, because the exiled intellectual - who has often lived an opposition to the exiling system in an active way - now lives a misrepresentation between the intent of his or her fight and the condition of exile. And in the transition from the obscurantism and the authoritarian violence towards the yearned-for democracy, the political outcomes proceed cloudily and induce a feeling of unrelatedness, which leads to another kind of exile, carried out afterwards and often superimposed to the migrant mobility concerning postcolonial logics [8][2a]. Therefore some kinds of exile are not less awful than the traditional one: actually, they share the intrapsychic dimensions of an extreme and irreconciliable irrelevance [9], in addition to several aesthetic and linguistic peculiarities.

The latest studies, carried out in Cambridge [10], show that this departure, implying a constant slide between the various levels of proximity in the different and globalized literary realities, generates an interpenetration and some urgencies that are ascribable to the unifying and recurring perspective of the duty to memory and its sacral experience [11]. Within the experience of exile, the scarcity in material possessions and the mutual feeling of vulnerability and nakedness can lead these authors to make use of their physical dimension as a final complaint: the body, with its own vulnerability, is an extreme, stentorian, assertive and, broadly speaking, linguistic of identity. [12]

If one's identity is in their body, the creative merger of memory occurs with the establishment of a loyal relationship to the mother tongue as a very last homeland. And the body becomes a meaningful, fundamental linguistic promoter of those contents dealing with cultural and unanimous identity and memory, and the literature is their witness.

Along with the recurring dichotomy between genre attributions - particularly between the masculine, rational part, which characterizes the legal origin, the land, and the feminine element, which defines the feeling of cultural and emotional identity as first referent of a legal, national identity - there is a conservation of the mother tongue, which does not replace the host language but outlives it or comes up beside it [13], in order to define a self-perceived bond between the exiled author and his community context. The reference community not only is the object of one's expressiveness, belonging to both the world of the exiled and the hosting world, it is also the actual milieu and speaking community through the writer's gesture: he writes through his own single voice the numerous and concentric ehoes, implied by his dimension of defender and proponent.
This theme settles in the classical literature ${ }^{\mathrm{i}}$ and characterizes the Western identity itself $\mathrm{f}^{\mathrm{ii}}$, even in its religious appearance, since monotheistic creeds open human history with the exile from Eden.

The subject also developed in the original Italian literature, starting from Sicilian poetry with the presence of exiled intellectuals within its court and exile errant figures - first among everyone is Dante Alighieri - who worked at the heart of Italian literature itself [8][14]; this kind of literature aimed at a strong creative affirmation with a particular attention to linguistic awareness. The motif also proceeded through emblematic figures (such as Machiavelli, Alfieri and Foscolo), who represented the reflection of those historic and political peculiarities - following the path of the not-so-far officially Italian history and geography -, which left their mark in the country's literary appearance.

Ultimately, within the recurring dynamics of the exile works and according to Lionnet and Heath [12: 30-40], the literary fiction becomes the place where the myth of authenticity can be founded and pursued. This dream absorbs - in its extreme consequences - the condition of the exiled, the individual who put him- or herself above the community law, and the condition of the sacred, the individual who, according to Agamben's fundamental reenactment [15], is external and unrelated to the original community, the original one and as well as the community of men. In fact, he is destined to the heavenly judgement through the atoning sacrifice: the exile is banished in an extra-human symbolic dimension.

\subsection{Gëzim Hajdari}

Gëzim Hajdari was born in Hajdaria (Lushnjë), Albania, in $1957^{\mathrm{iii}}$.

He runs the Erranze series for Ensemble, a publishing company of Rome, and lives on lectures and conferences in different European universities: nevertheless, he still does not benefit from either an economic stability or an establishment of his own poetic work.

In Italy he keeps on doing what he commenced in Albania: denouncing the oppression of intellectuals and poets throughout the XX century and during Hoxha's communist regime; as well as reporting the political and economic corruption in Albania.

Since his debut, in 1993, his work has been characterised by a parallel and bilingual (Albanian and Italian) directive ${ }^{\text {iv }}$.

Thanks to his poetic research, he has been nominated for the Noble Prize on various occasions.

During the past few years the interest in his work - mainly expressed within the French- and English-speaking world by interviews and academic studies - has been accomplished thanks to the translation of some of his compendia: in 2007, Mondkrank. Pop Verlagcon, translated from Italian by Stefanie Golisch [17]; Maldiluna y Rosa canina, Editorial Aurora Boreal e-book, 2015, chosen and translated by Mario Camelo [18]; Stigmata, translated by Cristina Viti and 
published in 2016 for Shearsman Books, Bristol [19], both in Italian and English; Balkan Blues [20]: translation in French, Italian and Albanian from Corpo presente, translated and presented by Alexandre Zotos, with an annotation by Nils Anderson, for Classi Edizioni.

\section{Materials and Methods}

\subsection{Methods}

In order to frame Hajdari's complex poetic and literary profile in a more extensive and clear way, I am going to provide a careful textual analysis concerning the main lines of research, which have been developed about the author. The analysis will also include the relevant historical and literary picture.

\subsection{Materials}

Along with Marcía Theóphílo, Hajdari is considered the main Italian-speaking poet. Hajdari is the only non-Italian poet, who lives in Italy, whose work has been analysed by three monographic studies: in 2010, the compendium of essays: Poesia dell'esilio. saggi su Gëzim Hajdai, edited by Andrea Gazzoni for Cosmo Iannone Editore [21]; Alessandra Mattei's monography: La Besa violata. Eresia e vivificazione nell'opera poetica di Gëzim Hajdari, Ensemble Edizioni, 2014 [22]; Sara Di Gianvito’s In Balia delle dimore oscure, Besa, 2015 [23].

These three publications confirm a growing interest in Hajdari's work, a very active interest within the international study of literature, above all the postcolonial and migrant literature. We can mention the chapter dedicated to Hajdari in Ugo Fracassa's Patria e Lettere [24]; and the constant research on the Italian-speaking migrant poetry, with a particular attention to the author, carried out by Flaviano Pisanelli [25] and Laura Toppan [26]. These studies are mostly focused on the overcoming of monolinguistic and solipsistic national cultural identities within the reconstruction of a cross unitarity, provided by the amalgam between Mediterranean consciousness and universe.

Recently the English literary and academic world has begun to become interested in Hajdari's poetic and cultural work, spreading it thanks to the translations that have been released on magazines and newspapers. After an interview for the Herald International Tribune in 2000, a first selection from his writings made its appearance in 2011; it was edited by Mia Lecomte and Luigi Bonaffini. The anthology brought the attention on the need to create anthologies about the poetic works of those who have been migrating to Italy: $A$ New Map: The Poetry of Migrant Writers in Italy (series supervised by Gaetano Cipolla) for Legas [27]. Then the interview and the translation by Anita Pinzi appeared on Warscapes [28]; «America Oggi / “Oggi7», 2014; a translation for A public space [14], «A Public Space», 2015;
«Lunch Ticket», 2015; «Antioch University Los Angeles», 2015; «Notre Dame Review» (University of Notre Dame), 2015; «Structo Magazine», 2015; up to the extract of Poema dell'esilio, translated by Anita Pinzi and released on Mosaici [29] in 2016; six poems were released on MPT [30] with Viktor Berberi's translation; and the extract of five poems from Erbamara, translated by Ian Seed and released on Fornightly review[31]; finally Patrick Barron's illustrious translation for the essay on New Italians released on World Without Borders [32].

The writings, translations and interviews in English have generously favoured the extraordinary nature of the testimonial experience that Hajdari's poetics pursues, by underlying the breaking system that the poet's work entails within the main Italian tradition. For example we can read what Viktor Berberi writes in his introduction to the translated poems [31]:

The arc of Hajdari's career demonstrates the courage with which he has held tight to his own voice, however at odds with contemporary trends in Italian literature. Perhaps the most striking aspect of Hajdari's work is its complete dedication to renewing poetry task of speaking as the voice of its time. As he tends the memory of a people's past, Hajdari documents the existential condition of the exile and migrant and calls his readers to an encounter with other worlds.

An outspoken critic of both the Communist and post-Communist political class in Albania, Hajdari has collected accounts of the innumerable literary figures persecuted under Hoxha's regime in his Gjëmë: Genocidi I poezisë shqipe (Funeral Lament: The Genocide of Albanian Poetry). Indeed, his entire output can be read as a struggle to restore a voice to the voiceless, whether those suppressed by a brutal dictatorship, those who have been forced to abandon their homelands, or the others left behind to suffer poverty and violence. The [...] poems are characterized by a movement across borders (cultural, political, linguistic) and between present and past, looking back from Hajdari's current home in Italy to the landscape, language and legends of the Albanian province of Darsìa. Hajdari's great gift to Italian literature lies in his having brought to bear in his contemporary poems in Italian the richness of an ancient Balkan, and, more specifically, northern Albanian, epic tradition.

The lyric structure we find in the whole Hajdari's poetics does not consume the cause for interest that his poetry provides.

Since his first compendium, Ombra di Cane, 1993 [35], the aim of denouncing the horror of a country devastated by a dictatorship and by the dejection for a blurry political system after the fall of the communist regime in Albania is justaxposed by a specific aesthetic sense of the lyric output. The Western social economic and literary model - embodied, par excellence, in the Italian one - is also criticized: it is not always able to understand and embrace the peculiarities of a time in constant change, and to overcome the preconception 
of an initial economic disadvantage that people and culture integration meets within a deeper and more radical cultural economics; furthermore, the drawing from the intercultural active thought is tied to the reconsideration of the world according to the theories on postcolonial, migrant and world literature ${ }^{\mathrm{v}}$, that in Italy have actually been accepted late. And now, although they are getting credit progressively, they are enduring the initial slipping.

Hajdari's work is made up by nine poetry books, a lyric drama, a poem on exile, two travel books and a testimonial book, in addition to the curatorship and translation of two Albanian anthologies.

Despite the different poetic genres, Hajdari entwines recognisable features of composition and creation, such as the ethic structure, the testimonial and remembrance duty, the development of a common consciousness allowing the creation of a semantic universe that may be naturally shared and accessed by his heterogeneous readers. He makes full use of the Mediterranean nature, of the Italian cultural heritage and consciousness, of the Western classic Mediterranean, middle-Eastern, Semitic, Sumerian, Egyptian, Albanian traditional heritage.

The creation of this strict one-to-one signification universe, which aims at allowing a natural flow of the lyric ego between East and West without going beyond his or her own identity, is fulfilled in the poetic series named Erranze, run by Hajdari for Ensemble, Matteo Chiavarone's publishing company.

This series, focused on spreading the poetic works able to generate a real and profound flow of poetic vibrations from different traditions otherwise not available in Italy, counts six titles. The opening work is the two-act dramatic poem Nûr [36], which represents the level of maximum synthesis of the poetic question extending from his previous compendia: herein the favourite style of poem is accomplished following the increasing goals chased in his ending short poems of the compendia Maldiluna [37] and Peligorga[38]; and it blends with a theatrical aim that the theme of exile brings on as a duty to the grave.

As a matter of fact in the afterword of the poem, Gazzoni highlights [36: 134] the infighting that characterize Hajdari's previous work, generally expressed by some constant binary antithesis - here and elsewhere, self and other (when "other" is always a feminine otherness), world of nature and human world (with its annihilated and silent reality), the biographic existential value and the symbol - which, being strengthened and recomposed in a profound semiotic twisting, impose the open epic intentio and the ancient tragic one.

Basically, the classic latin and greek world is used to overturn a model of self-referential culture, like the Western one itself. The most obvious example is probably the rewriting of the fire of Ilios in Book II of the Aeneid by Virgil in the scene describing the fire of Rome in act I of Nûr, where the new Aeneas dies by crucifixion, sacrifying himself to overcome the irreconcilable atavistic distance that the identity of Malsor ${ }^{\text {vi }}$ considers as regards to strangers' identity. The Christological image - representing the son who sacrifices himself for salvation and new life - is superimposed to the heretic image of Giordano Bruno burned at the stake because of his sin - and magnifies the complexity of the creation of references; it also adds a second reading level that recalls the myth about the dismemberment of Orpheus - widespread in the old Mediterranean world - and actualizes the obligation of scattering ashes, existing within Hajdari's previous compendia.

This connects to the theme expressed in Poema dell'esilio [39], his first work that clearly reconstructs and denounces the abuse of power and poets' decimation in Albania throughout the XX century and the communist regime.

Choosing the style of the poem confirms the epic therefore collective - goal acquired by the poetic work.

More specifically, the reconstruction of some peculiar subjects, such as the superimposition of 'Hector traiectus' figure (Book II of Aeneid, vv. 270-279 and Book XXII of Iliad, vv. 395-409) with Musine Kokalari's figure [39: 163] drawn by her feet by a garbage truck as an ultimate insult to the intellectual's corpse - ties the classical references to the event of exile as a moral obligation in the name of a collective good; an obligation to the grave, as it has been specified elsewhere [22:159-258], that finds its best intelligibility in Epicedio albanese, released in Tirana in 2010 and forthcoming in Italy [40].

Tying the text to Hajdaris' previous poetical writing allows to discover another classical source as regards the theme on obligation; this was stated beforehand in the short poem Occidente dov'è la tua besa? within the compendium Spine nere [41].

According to the author being obliged to react and despise the relentlessness of the evil, which is inherent to men, refers to the classical Greek heritage. It leads to guarantee a cross intelligibility of the message, generating from clearer references relevant to the Albanian tradition. In particular the obligation to the grave - suspended between the manifested bareness of the individual who enacts his/her own opposition through a gesture and the symbol that it is meant to exist cannot recall but the crux of meaning expressed in Sophocle's Antigone.

Starting from the story of a recurrent interdict of the grave that Hoxha used to reserve to his enemies - most of whom were intellectuals that had been studying abroad or had not been conforming to the regime - Hajdari intends the exile as a transposition of the intangible body - the remembrance outside the original homeland. The voluntary exile is a sort of fertile grave: for the offence to identity, threatened by the homogenisation that the dictatorship required (to prove and denounce its brutality, he releases a book made of communist slogans, Evviva il canto del gallo nel villaggio comunista [42]); for the receiving Western and Italian cultures, as they are involved in a self-referential monologue on aesthetic issues and questions, not necessarily to be dealt with in a specific period of time. 
In this kind of writing the moral nature never renounces either a very high lyric poetry with its compelling verses or an analysis of nature which becomes a universal reference, an easily intelligible reference since it's tied to recognisable data: arboreal essences, nocturnal landscapes, erotic yearnings intertwine the bucolic tradition to the Leopardian and classical Arabic poetry, aiming at creating a huge emotional universe of reference able to imply the unanimous identity characterizing the Mediterranean man.

Herein the Mediterranean Sea is a figure that allows a flow of ideas and references towards a whole poetry/culture, a world poetry/culture, of which Nîr is the first tile, thanks to its perfect equilibrium between Mediterranean high culture and Albanian oral traditional culture.

After his tragic epic poem, Hajdari keeps on chasing his goal through the editorial choices for Erranze series: to provide a classical expertise coming from traditions not belonging to the Western European one, in order to create a common classicism that may be the reference to a world-poetics, as the Mediterranean classicism had represented to the poet up to Nûr. This is why, in addition to Leggenda della mia nascita by Besnik Mustafaj (Ensemble, 2012) and Fuorivia by Luigi Manzi (Ensemble, 2013), he releases Gemino Abad's first anthology - Là dove le parole non si spezzano ${ }^{\text {vii }}$ [43], winner of Feronia Prize 2009 - and Diritti di passaggio by Kamau Brathwaite [44], availing himself of Andrea Gazzoni's translation. Recently he edited - for Ensemble's series Transculturazione run by prof. Gnisci - an important collection of essays, Pensiero caraibico [45], in which we can read Walcott, Glissand, Carpentier and Brathwaite's considerations about an extra-European nature, as the paradigm of a new "mediterraneanism" within the Caribbean postcolonial ulyssian melting pot, an update of the thousand-year-old European standard.

The choice and release of the last two books for the series run by Hajdari are focused on establishing a new, open and reconstructed classicism: toward the Antilles' universe - a new melting pot and paradigm of reference for a possible poetics of relation, as Glissand defines it - and the Far East drawn near him in his first travel reportage [46], where the difficulties faced by intellectuals, due to a blurry politics and a status of deprivation and uncertainty, implicate a harmonic cohesion between the Albanian poet and Abad's experiences.

In Hajdari's opinion this is necessary because the poet reads the classical paradigm as a guarantor of a cross and converging intelligibility, which allows to experience a global literature able to effectively communicate and understand contemporary needs. Aiming at setting this interpretative line for a functioning literary scenario where a world-poetics is possible, Hajdari concludes his series with his own compendia, Delta del mio fiume [22].

The poetic work, whilst confirming the ordinary moral guidelines of testimony and remembrance and keeping its own original Albanian identity - also linguistic -, develops an open way of thinking and composing; it is dialectically open between the original and final ones that has been never reduced to a global identity in his previous works.

More specifically, he starts from the ordinary classical Latin reference with an opening work recalling Aeneid's Rome and the figure of Pius Enea - whose illusory defeat allows to create an immortal cultural system based on order, beauty and justice - then changes setting completely, by replacing the classical Italian scenario (paradigm of the irreconcilable but necessary otherness to enact his perpetual exile) with a new and additional otherness. This has been already explored with his travel reportages (Mugunzu in 2006 and the reportage on the Far East) and the release of Abad's anthology.

The usual composition technique of his eight previous compendia considered the natural world as an effective trait d'union for both the poet's and his readers' experiencing sensitivity. Herein it is exalted, since the African natural heritage is not common in the Western culture, and the choice of a seductive Panic exalts the environmental and cultural complexities of the African continent, by letting it be experienced through the common sense of a known cultural context albeit not properly explored.

The beauty of the area, the reference to a fierce and overwhelming naturalness of life give rise to a candid eroticism in the short poems recalling, for their style and theme, Maldiluna and Rosa Canina [37], and especially Contadino della tua vigna at the end of Peligorga: Fare il contadino della poesia, closing Delta del tuo fiume, brings on the continuity of the experience described in Nûr, a continuity that is fulfilled in the communication between Albanian traditional culture and Western culture.

The strategy of this communication - that is being $a$ living body in the poet's world - is expanded in Delta by a lonely corporal identity in the dynamism of a stateless person, who finds his/her roots in the key existential experience of the lyric self; this is represented by Albania, a maternal and creating dimension in its lingual-emotional significance, and by the poetic experience of other places, seen as stages of the never-ending journey that is becoming a man, as well as being dweller and beneficiary of the poetry of those traditions which are invoked in a synchrony of time and space external to any historical and literary reference but accepted as a personal dimension of creating a poetic sensitivity.

Poets of these traditions await as guarantors of the deal implied by the educational journey illustrated within the compendium: Senghor and Brathwaite [16: 28, first and last stanzas] Tagore [16: 90], Li Po and Du Fu [16: 96] coexist as references for the reconstruction of a parallel poetic world, contiguous to the real world.

As Giorgio Linguaglossa states, the epic structure keeps a strict, almost imposing, dimension [16: 11]:

$[\ldots]$ The Panic aspect of Gëzim Hajdari's poetry is the direct consequence of his disobedience to the world's unfair laws, which sanction his exile [...] 
The homogeneous nature of Hajdari's poetic world is apparently dismantled by an utter openness to the consciousness explored in his journeys. Within the anthology Recentiore it is recreated by inweaving existing subjects. For example in Spine nere, the recurrent figure of black clouds is evoked in the poems with Ugandan settings [16: 105; 111; 113]; or the hints to autobiographical stories in Maldiluna and Stigmate found in the first and fourth stanzas of Custode della mia uva [16: 132], which sets up the recreation of the first semantic universe and the Mediterranean consciousness in specific time-and-space motifs, characterised by an unchanging season - spring - and naturalistic features, such as the Judas tree in Custode della mia uva [16: 137], where it is mentioned after listing all the destinations he reached, from Africa to the Far East and Africa again.

The foundational equivalence between Mediterranean and new global classicism is clearer when you notice that the closing short poem of the compendium is Delta del mio fiume [16: 143], where the whole poet's biographical sequence of events is remembered and the frequent usage of basic themes is confirmed: the fundamental value of exile; the body as a means of writing and first signifier; all Balkan traditional motifs in Fiaba di Costantino that represent the structure of the Act II in Nûr, whereas here it is the subject of the poem's last stanza. The reconciliation with the themes we find in Nûr is anticipated by the short epigrammatic work $\mathrm{Nel}$ sonno africano sento la voce di Nûr [16: 115]. Here the author reaffirms his sacred origin - pushed away, yet not lost - and the need to experience his exile in order to create a profound and fruitful relationship between the major culture and those literary traditions that are important and still not dominant.

\section{Results}

It is manifest that these further developments towards a World literature cannot exclude the poet's lyric nucleus. As a matter of fact he does not distance himself from the aim to create a figurative world through the foundation of a common and approachable consciousness. The poet's voice makes use of the epic spirit for its unanimous value, which guarantees an immediate approach to the poetic universe he created.

Apparently it is a natural universe, but this universe has been chosen and reconstructed thanks to reality: hill landscapes, arboreal essences, typical Mediterranean flora and fauna (brooms, Judas trees, blackbirds, etc.). They cause an emotional short circuit inside the poet, who splits the sense into two features: his origin and his current residence. Still the experience is utterly intelligible.

As Gazzoni highlighted the poet lives in a sort of extreme twisting of the subject [36: 128]: he deals with his status of exile as a condition of atopia. Although the exile is a painful separation from one's origin, the exile him- or herself strives to put an end to this separation.
Hajdari does not want to rectify his exile condition, because he considers his homeland as a gorgon that caused this separation. It is a suspension between the original and the current dimensions: where the first has been pushed away with the exile, the latter has never been conquered completely. It is a nonplace, founded by an apparently real imagination of his poetic creation.

This is a world that expresses a complex structure in its tangible appearance. Moreover the structure is tied to elements, cultural and erudite motifs whose perceived affinity - generated by the common origin of the host culture - introduces the reader to Hajdari's poetic universe without breaking the experiential familiar world.

As the poet recounts about full moons, bucolic contexts, magic and sacred value of traditional literary subjects, he leads the readers themselves to the same non-place, by driving them to renown contexts relevant to the cultural construction of self, and by recalling unconscious affinities to classical poetic references such as Leopardi and Virgil [23: 46-81]. In my opinion the space and time suspension that traps the poet in his writing situation needs to be connected to the epic value of the poem in his condition of exile.

Within the classical tradition which Hajdari refers to [23: 20-130], epic is the poetic tale that addresses an entire community through one individual's story. In his poetic creation, Hajdari has two referential communities: the Italian-Western one - in which he lives actively and refuses to integrate his own identity - and the original community which he cannot define to his own eyes.

When he chooses the exile voluntarily as the only possible interaction, he also bestows a double value to it: on the one hand it is Matria - the emotional condition of his own human and cultural definition -, on the other hand it is a feminine figure, heralding life in its incarnation of the erotypical power belonging to the natural world, to which he connects himself in order to create his own endurance. Therefore his original homeland is the language he never leaves behind in his work, and the language itself embodies the distant homeland expressed by his own voice and his deuteragonist in Nûr.

To Hajdari the preservation and usage of Albanian are the deepest form of loyalty to his origin. Thus, the introduction to the Italian poetry of a part of the Albanian cultural tradition is not fortuitous: the oral and popular tradition of the legend of Constantine, as well as Kanun, which is the fundamental text for Malsor ${ }^{\text {viii }}$ culture at an anthropological level, due to its triple oral nature. Traditional, normative and literary. It is a mythical research for an origin otherwise indefinable, counterposed to the execrable circumstances of his time.

Where other exiled intellectuals' experiences highlighted that the civil society could be divided into an atrocious part and a good part - where one might hope to reconstruct the society to return to - in Hajdari this hope is really small, since the free and good part of the country he fled from does not reside within the society itself. It is not his epos' people, but 
it is the class of intellectual martyrs whose decimation is illustrated in Epicedio albanese [40].

Thus this ghost-population does not benefit from the story of Pius Gëzim's [23: 223] risks and suffering to create a haven where he might start his earthly existence again; it is an epos living in the memory of the mission carried out by Hajdari's journey.

According to the classical interpretation by the so called School of Harvard, Virgil's works express a consideration about the nature of evil and the value of the violence of power, which is able to turn victims into violent beings themselves.

Actually the violence of power is the main subject in Epicedio albanese, where the narration of the decimation techniques accomplishes the manifest condemnation launched in Poema dell'Esilio.

Certainly, the nature of evil, studied in this important text, does not exclude the obligation to react that Hajdari feels like carrying out.

He is aware of the finiteness to be a human being in front of the excessive magnitude of power and evil, this is why he wonders what answer he is supposed to give to the unrestrained evil, the outcome of the abuse of power. $\mathrm{He}$ wonders what value the positive right of dictatorship had against to the natural value of a human being who experiences pain. An obligation to responsibility is the impetus of his epic exile, which lacks of a real referential community.

This question - which connects power, natural law and responsibility - pushes Hajdari into the Greek tragic classicism and leads the poet to Sophocle's thought: Antigone represents the obligation to the grave. It is the answer to these questions.

Progressively Hajdari redrafts the theme more and more extensiely: at first, within Epicedio, he recounts about those who could not attend the burial of intellectuals and opponents died in the concentration camps, promulgated by Hoxha's apparatus and compared to Creon's decree; then the poet makes a comparison between his own exile and the vailing of Polyneices' body by Antigone.

In fact, like the earth on Polyneices' body disregards Creon's order, Hajdari refuses to deny the memory dictated by his country's political situation as well, when he expresses his own essential identity in the exile.

The poet deals with the theme of the grave extensively and summarises his thought in the compendium titled Spine nere [41: 51] - related to the subsequent development of Nûr and considered as a thematic glue of the last lyric works of Ugandan setting and Delta $[16: 109 ; 111 ; 113 ; 115]-$; herein he describes the finiteness and vulnerability of his own invisible migrant's body as a double of the ghosts, whose memory needs to be honoured through the figurative ritual of a possible burial.

The figure of ghosts, ethereal memorial objects, makes its appearance in the first poems collected in Corpo presente [48: $12 ; 20]$ : the corporal dimension is clearly fundamental, since it is able to define the signifiers of the poetic act carried out by a poet - a migrant, an outsider of both Italian and Albanian literature - who chooses this insuppressible status as an assertive condition for both his existence and poetic subject.

Within this compendium the body acquires a total centrality: as a poetic instrument, it resonates in the wind and suffers from the painful naturalistic output of the stark lands where the memory and the pain take place; or it enjoys the beauty of nature which opens up after the reified and urban landscapes of the first compendia.

Much to the advantage of this dissertation, two poems included in the English precious and unique anthology of Italian migrant writers $A$ New map. The poetry of migrant writers in Italy [28: 128-130] - are reported below, thanks to Mia Lecomte and Luigi Bonaffini (editor and translator) who permitted their use herein.

\section{Nella valle}

Resterà la sabbia sterile arata dal serpente

Alberi stretti tra loro come negli anni di fame

gridano al cielo parole

che aggravano il linguaggio dei morti

Vanno sul filo del disastro uomini e bestie

(uniti nel silenzio e nello spazio)

finché raggiungono un territorio brullo senza infanzia.

\section{In the valley}

The sterile sand will go on being ploughed by the serpent Narrow trees among them as in the hungry years

cry words out to the sky that aggravate the language of the dead

Men and beasts move along the edge of disaster

(joined in silenceand in space)

until they come to a barren zone without infancy.

\section{Tu esisti di fronte all' inverno}

Tu esisti di fronte all'inverno come una ferita. Immobile e forestiera in uno spazio imperfetto, mai ospitale aspettando che il silenzio uniforme della sabbia ti parli del segreto. Non ti stordire dei fiumi vaganti e dei nuovi alberi che prima non c'erano. D'intorno continuerà la caducità delle cose la scomparsa dei poeti che legano il cielo con la terra.

È detto che moriremo nelle terre opposte. I miei anni: fuga nell'ignoto e risvegli spaventati nelle notti.

\section{You exist before the winter like a wound}

You exist before the winter like a wound. Immobile and a foreigner in a place imperfect, always inhospitable 
where you are waiting for the monotonous silence of the sand

to speak to you of the secret. Not to dazzle your eyes with wandering rivers and new trees that weren't here before. And all around it will go on, the frailty of things the vanishing of poets who connect the earth and heaven.

They say that we will die in opposing lands. My years: a flight through the unknown and dreadful awakenings in the middle of the night.

Using his own body and fighting the imposition of oblivion with his own existence is a reaction chosen by the poet, who deconstructs Antigone's act [23: 120-134] in a gesture. In a more recent Agamben's thought [49] on iper-contemporaneity, this category is an act lacking of assertive implications, though it is able to provide a way out, thanks to its resolute will in its slightest dimension. Hajdari's individual and solitary dimension as exiled denounces the impossibility to go through the exile by means of a new affinity, because of the disabled dimension of his own specific morality. He is considered as a referent of his own epos - no longer alive - which he gives the credit for a serving break-up among the values of poetics and freedom, violated by persecution and prohibition to the memory.

A journey and an epic poem lacking of a real referent: this explains why, in the works from Corpo presente up to now, main figures are rather orphic than christologic and why in $N \hat{u} r$ - that should represent the clearing of the author's double dimension - a fusion can be only fullfilled through Gëzim's lyric self. He keeps a feminine maternal and traditional double to create his dramatic poem on the basis of two counterposed acts, where Western epic poetry dominates the first act, and the Albanian oral tradition stands out in the second act. The Western epic poetry is a reference to Aeneid in the urban context of Rome and in the christological-orphic figure of the hero, crucified and burned at stake, who sacrificed himself to overcome the distance (figuratively he buries the ashes of Penates and perished people, victims of slaughter and dictatorship, who find a new homeland in this gesture). In the second act the Albanian oral tradition has been redrafted in compliance with Italian traditional variants, yet it is still tied to the chthonic space of the dead, of the desperate sacrifice in the name of besax. The clearing of the exile condition occurs on a path of communion that can be accessed by others: the poet does not emancipate from the solitude and uniqueness of his own poetic mission. He keeps going to create an irreconcilable circularity that spreads energy and poetic heritage towards a knowledge, which is no longer a unanimous Western consciousness: this knowledge tends to achieve a global availability through his editorial choices, putting in writing the poetic book Delta del mio fiume.

In Hajdari's poetics the body is a crucial element, it is the manifest functional and figurative nucleus of his entire work.

Some powerful signifying peculiarities are assigned to the body. Being the means to the author's testimonial achievement, it acts and echoes just like the natural mixture that creates the significability within Hajdari's lyric structure.

Like the bucolic nature in which the body acts, it resonates like the skin of a snake, or trembles like the shades within a world of terrible, anti-human memory and inhospitable present. Being both the linguistic signifier and signified, the body takes part in an actual philosophical thought recalling bio-political questions to be fulfill in Nûr. And the clearing of those stances that were expressed in the tragic poem - and that should have concluded the whole Italian period of Hajdari's consideration - are finally fulfilled in Delta del mio fiume. Here the body - at first offered for a semantization of the Western culture that was focused on erudition rather than considering the actual needs of a specific period - is replaced by an erotic body, originating in some poems of the author's previous poetic collections and thickening in Contadino della tua vigna within the compendium Peligorga [38: 110-129]. It foreruns and prepares the experience of Nûr and is clearly realized in the erotia throughout Delta, where the erotic body of both the observer and the observed is an interpretative means to the experiential reality of the places he visits. It also becomes the foundational actualisation of the orphic body.

\subsection{The Poetics of Crossing in Erranze Series after Nûr: Delta Del Mio Fiume and his first Translation in Three Languages}

If we consider N $\hat{u} r$ as the turning point of Hajdari's thought about the realization of his own original identity within a reviving relationship with the host identity, it is possible to close off a continuous function of roaming for both the lyric and biographical self, as the condition to an active and boundless crossing, able to provide the impossibility to leave the eternal itinerant situation of the poet's voluntary exile.

On the contrary, the integration of the poetic nucleus' original tradition moves forward thanks to those proactive fusions, which emulate rhapsod's ancient motif and multiply a world that expresses the author's message actively, through the stimulation of the hearing. The latter is based on a skillful reconstruction of a referential common feeling, which in turn is founded on an experiential universality and an acknowledgement of prestige relevant to common literary and cultural sources.

Therefore, the latest translation of one of Hajdari's work may be read in these terms. Balkan Blues [21] was released in the last months of 2016 for the international publishing company Classi, embracing one of his compendia in a three-language edition (French, Italian and Albanian) for the first time: Corpo presente.

Taking into account that to Hajdari the linguistic question corresponds to the thematic development, it is easy to understand that this choice of authorial mark is very important. 
Recalling Hajdari's linguistic lyrical peculiarities, the double drafting - almost obsessive - into both the Albanian and Italian languages. It also works for those books - such as Epicedio Albanese - that have not been released in Italy yet; therefore it is not a simple editorial need, it is an evidence for the existential dimension in which the author's exile operates. It is a sort of double place creating a space, otherwise not existing for oneself or others, in which you can confront with your own phantasmal epos, which acts as reviving response.

Starting from Maldiluna the linguistic priority changes and the mental order, allowing to connect process and translation, is undermined; so is the layout order of the previous Albanian main text (on the left) with the Italian translation (on the right). The graphic overturning likely corresponds to the overturning of power between these two languages-identities, that the author inversely stabilizes by means of a technique usually used at the beginning of his work: he introduces into his lyric poems a heftier and clearer reference to his original cultural tradition, by keeping untranslated names and words.

These references are always intelligible, thanks to the general sense of lyrics and stories, as well as the reconstructed nature as an objective correlative of the context that cannot be misinterpreted and that serves as a bridge between different cultural and linguistic systems.

In $N \hat{u} r$, where the interlinguistic existential reflections were supposed to be arranged, the relation between Albanian and Italian is overturned again and so is it in Delta.

Therefore the presence of three languages is not fortuitous; moreover Italian and Albanian are not two languages that sacrifice themselves to French within the translation strategies carried out in Balkan blues.

The choice of bilingualism has been made after selecting poems for Erranze series and after Delta was released, where the author aims at crossing different traditions in order to find a cross medium allowing to realize Hajdari's obligation to exile, ashes and grave; and where it's possible to identify foundational, poetic and aesthetic values in different traditions in order to create an actual world literature.

\section{Discussion}

Gëzim Hajdari is an important contemporary poet, exponent of migrant literature, who has drawn several academics' attention to his own figure and authorial peculiarities. The studies on his work are unusually copious in comparison to what literary criticism averagely provides in Italy about migrant poets.

Most of these researches, as well as the richer French interest towards the author, have favoured a moral overview and analysis in order to address the phenomenon of his ample and esteemed work towards the civic appreciation of Hajdari's intellectual activity and poetic choices.

This approach turned out to be effective to focus an incisive interest within the field of study that suffered from a noticeable delay in Italy in comparison to other leading literary traditions.

I think it might be useful to employ techniques relevant to textual analysis in order to support the didactic achievements reached during the last decade by those innovative and precious works that have embraced such an important poetic voice within the international background.

Taking into account textual aesthetics and themes of denunciation of Hajdari's lyric self, I try to demonstrate that his poetic corpus makes use of intra- and intertextual structures along with moral goals.

Linguistic choices, signification strategies, selecting referential genres, progressive chronology - polycentric yet expanding concentrically - relevant to the themes concerned, allow to explore editorial logics, as well as structural background logics within and through which the author operates and aims at providing guidelines for the global literary discussion and work.

And since such a complex writing experience leads to several questions, we need to wonder in what conscious relation he lays his own experience. This can be assessed through an autobiographic narrative that aims at becoming memory of a perished community, or, as Giuliana Benvenuti would say, necromancy [50].

In the end the peculiarity of his epic subject, lacking of a direct reference for the heroic situation of his individual ordeal, may favour a pristine deliberation about features of contemporary epic poetry, characterizing most of present postcolonial poetics.

\section{Conclusions}

A close-range observation of Gëzim Hajdari's authorial and editorial dynamics - through the effective use of repeated classical motifs as well as the cultural references to Mediterraneity as first place of influence and relationship allows to define the tendency to create a world literature that the poet wants to ingrain into his latest work and in which he wants to be actively involved, by making some selection, translation and release choices for the series he runs.

Within the Italian background this must be considered as a significant and stimulating incentive to generate solid reflections for both an available production able to create a world literature and a development of a steadfast incisive attention to detect its signals.

\section{REFERENCES}

[1] A. Seyhan, Writing outside the nation, Princeton University press, 2001

[2] E. SAÏD, Culture and imperialism, New York, Alfred A. Knopf, Inc., 1993. (2b) E. Saïd, Reflections on Exile and Other Essays. Cambridge: Harvard UP, 2000 
[3] E. J. Hobsbawm, The Age of Extremes: The Short Twentieth Century, 1914-1991, Michael Joseph (UK), Vintage Books (U.S.), 1994

[4] N. Iglesias-Franch, The Space of Freedom in a Context of War, Exile and Endless Instability: A Sociolinguistic Approach to Autobiographical Narratives on Catalan Exile, Forum for Modern Language Studies (52: 3 , pp. 346-361), 2016, July

[5] G. Sten, From exile Experience to Exile Studies in (pp. 21-37) Greiner, Bernhard (ed. and introd.); Theisohn, Philipp (introd.), in Placeless Topographies: Jewish Perspectives on the Literature of Exile, Tübingen, Germany, 2003

[6] A. Woolley, Contemporary Asylum Narratives. Representing Refugees in the Twenty-First Century, Palgrave Macmillan UK, 2014

[7] A. Nouss, La condition de l'exilé. Penser les migrations contemporaines, Paris, Maison des Sciences de l'Homme, coll. «Interventions», 2015

[8] J. BuRns, Exile Whitin Italy in Texts by Migrant Writers, (pp. 369-384)in (ed. by Dino S. Cervigni) Exile Literature, Annali d'Italianistica, Vol. 20, 2002

[9] S.A. BURR, Exile and [Re-]union: A Hermeneutic of Existential Exile, Thesis of Doctor of Liberal Studies, Faculty of The School of Continuing Studies and of The Graduate School of Arts and Sciences, Georgetown University, Washington, D.C. September 27, 2011

[10] I. RATIANI, (ed. and foreword), Literature in Exile: Emigrants' Fiction 20th Century Experience, Newcastle upon Tyne, England: Cambridge Scholars, 2016

[11] N. BIRKEM, History, memory and identity: Remembering the homeland in exile: city, University of New York, ProQuest Dissertations Publishing, 2007

[12] F. Lionnet, J. HeAth (translator), Inscriptions of Exile: The Body's Knowledge and the Myth of Authenticity, Callaloo: A Journal of African American and African Arts and Letters 30-40, 1992 Winter

[13] S. Martin, Choosing Exile: The Publisher Situated in the Place of Exile in (pp. 69-74) E. NunEz (ed. and introd.); B.M. GREENE, (ed.) Defining Ourselves: Black Writers in 90s, New York NY, Peter Lang, 1999

[14] G. Ulysse (réunis par), C.A.R.I., L'exil et l'exclusion dans la culture italienne, Publications de l'université de Provence, 1991. Actes du colloque Franco-Italien Aix-en-Provence 19-20-21 October 1989

[15] G. Agamben, Homo sacer, Torino, Einaudi, 1995

[16] G. Hajdari, Delta del mio fiume, Ensemble ed., Rome, 2015

[17] Mondkrank. Pop Verlag, 2007, (Ludwigsburg) Gedichte. Translated from Italian into German by Stefanie Golisch with facing-page Italian text, originally bilingual, Italian and Albanian.

[18] Maldiluna y rosa canina, Editorial Aurora Boreal ebook, 2015, selected and translated by Mario Camelo. Translated into Spanish with the Italian facing-page text, originally bilingual, Italian e Albanian. Maldiluna, Besa editions, 2005-2007
[19] Stigmata, Shearsman Books, Bristol, 2016 tradotto da Cristina Viti. Translated into English with the Italian facing-page text, originally bilingual, Italian e Albanian: Stigmate, Besa, Lecce, editions: 2002-2006-2016

[20] Stigmata, Shearsman Books, Bristol, 2016 tradotto da Cristina Viti. Translated into English with the Italian facing-page text, originally bilingual, Italian e Albanian: Stigmate, Besa, Lecce, editions: 2002-2006-2016

[21] Balkan Blues, Classi ed, Florence-Paris- Porto Alegre, 2016, translated by Alexandre Zotos. Translated into French with the original text in Albanian and Italian of the compendium: Corpo presente, Besa, 2011

[22] AA.VV. (edited by Andrea Gazzoni), Poesia dell'esilio. Saggi su Gezïm Hajdari, Cosmo Iannone editore, Isernia, 2010

[23] A. MAtTeI, La Besa violata. Eresia e vivificazione nell'opera poetica di Gezïm Hajdari, Ensemble edizioni, Roma, 2014

[24] S. Di Gianvito, In Balia delle dimore oscure, Besa, Lecce, 2015

[25] U. Fracassa, Patria e Lettere, Perrone editore, Roma, 2012

[26] F. PISANELLI, Habiter et écrire la frontière. La poésie italienne de la migration, in Dynamisme des langues, souveraineté des cultures (Actes du colloque international de Tunis, 15-17 avril 2010, Université de Carthage - ISLT de Tunis), M. Arfa Mensia et S. Saïd (sous la direction de), Publications de l'Institut Supérieur des Langues de Tunis, 2013, pp. 17-37

[27] F. PisANELl, Identité, espace, représentation: la poésie italophone du XXI siècle, in Dislocation culturelle et construction identitaire, K. Birat, Ch. Scheel, B. Zaugg (édit.), coll. «Littératures des mondes contemporains», série Amériques, n. 8, Université de Lorraine, 2012, p. 211-225. A.

[28] F. PISANELLI, La frontière invisible: la poésie italienne de la migration entre diglossie et 'dislocation', identité(s) et dépossession, in Italies, n. 13, Poeti d'oggi / Poètes italiens d'aujourd'hui, études réunies par Yannick Gouchan, Université de Provence, 2009, p. 487-507. W.P.

[29] F. PisAnElli, La poesia di genere, il genere nella poesia: la scrittura italiana della migrazione, Narrativa, n.s., n. 30, CRIX (Centre de Recherches Italiennes de l'Université Paris 10 - Nanterre), Paris, Presses Universitaires de Paris 10, 2008, pp. $215-227$

[30] F. Pisanelli, L'Autre Méditerranée. La poésie italienne de la migration, Notos. Espaces de la création: arts, écritures, utopies (revue en ligne), n.1, juin 2011

[31] F. PisAnelli, "Mania", "fobia", "filia": il postcoloniale tra letteratura-mondo e interculturalità, Narrativa, n.s., n. 33/34, CRIX (Centre de Recherches Italiennes de l'Université Paris 10 - Nanterre), Paris, Presses Universitaires de Paris 10, 2012, pp. 163-173

[32] L. Toppan (a cura di), Letteratura, Potere ed Etica. Laura Toppan dialoga con Gëzim Hajdari, in Scrivere altrovel Ecrire ailleurs. Letteratura e migrazione in Italia / Litérature et migration en Italie-Recherches n.10, 2013, pp. 27-47

[33] M. Lecomte, L. Bonaffini, A New Map. The Poetry of migrant writers in Italy, Legas, Mineola (NY)-Ottawa (ON), Volume XV, series editor: Gaetano Cipolla, 2011, pp. 116-136 
[34] Pinzi A. dialoga con Gëzim Hajdari, in www.warscape.com May, 23, 2013

[35] Gëzim Hajdari. Two poems in A public space, issue 22, winter 2015

[36] Prinzi-Hajdari in Mosaici, July 2016 http://www.mosaici.org.uk/?items=gezim-hajdari

[37] PRInZI-HAJdARI in Mosaici, July 2016 http://www.mosaici.org.uk/?items=gezim-hajdari

[38] G. HAJdARI, Six poems translated by Viktor Berberi, Modern Poetry Translation, n.1 2016

[39] http://www.mptmagazine.com/product/no1-2016-the-great-fli ght--161/

[40] G. HAJDARI, Five poems, translated by Ian Seed: http://fortnightlyreview.co.uk/2016/10/five-poems-hajdari/

[41] G. HAJDARI, I am leaving you Europe, translated by Patrick Barron on World without borders, September 2016 issue: There is No Map: New Italian(s)

[42] http://www.wordswithoutborders.org/article/original/septemb er-2016-italy-i-am-leaving-you-europe-gezim-hajdari-patrick -barron

[43] G. HAJDARI, Ombra di cane, Cosmo Iannone editore, Isernia, 1993

[44] G. HAJDARI, Nûr, Ensemble edizioni, Roma, 2012

[45] G. HAJDARI, Maldiluna, Besa, Lecce, 2005

i Among the several examples, we can mention Ovid's The Tristia Book II and Seneca's consolation epistles, particularly Consolatio ad Helviam.

See Aenea's exile figure, who founds the Western modern Roman culture under the value of champion for those who were defeated by the brutality of evil.

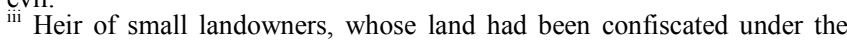
dictatorship, he ended up doing any jobs he found in order to study.

In 1991 he was one of the founders of the Democratic and the Republican parties: in 1992 he was in the running for the elections to the national parliament on Republicans' side. After several threats by the post-communist political class, in April 1992 he fled from Albania to settle in Italy, where he still lives.

He graduated in Contemporary Literature at the University of Rome "La Sapienza", in 1997 he was honoured with Premio Montale and some years later he reached the Presidency of the Award itself.

During those years he did humble jobs, among which stable boy and manual labourer; as he began publishing bilingual compendia in Albanian and Italian, he got the honorary citizenship in Frosinone thanks to literary and artistic merits.

iv It includes nine compendia, an epic poem, a tragic poem, two lyric anthologies, two travel books, a testimonial book (released in Albania in 2010 , forthcoming in Italy), the curatorship and translation of two books: one is about XIX century's traditional Albanian poetry, the other one is about Hoxha's regime slogans.

Postcolonial theories, mainly embraced in Italy, can be linked to two analogous and integrable fronts. Some of them develop from Gramsci, Said and Spivak's thought, from which comes De Robertis (2009; 2010), Comberiati (2012), Romeo (2014) and Negro's (2015) reflection, as well as the structure of the monographic issue of the periodical

Modernità Letteraria, edited by Rosanna Morace (monographic issue, n. 8 2015). Other theories are linked to Glissand's Caribbean thought, to which Armando Gnisci's interpretative style as well as Franca Sinopoli and Nora Moll's reflections are tied.

Gnisci runs the following editorial series: Transculturazione for the publishing company Ensemble of Rome, which recently released the first text about the Italian migrant theatre (Mauceri, M. Nicolai, Nuovo scenario italiano, Ensemble, Roma, 2015), and Kumacreola for Cosmo Iannone
[46] G. HAJdARI, Peligorga, Besa, Lecce, 2007

[47] G. Hajdari, Poema dell'esilio, Fara ed., Rimini, 2005

[48] G. HAJDARI, Gjëmë: Genocidi i poezisë shqipe, "Mësonjëtorja", Tirana, 2010

[49] G. HAJDARI, Spine nere, Besa, Lecce, 2004

[50] (edited by Gëzim Hajdari), Evviva il canto del gallo nel villaggio comunista, Besa, Lecce, 2013

[51] G. ABAD, Là dove le parole non si spezzano, Ensemble ed., Roma, 2015

[52] K. Brathwaite, Diritti di passaggio, Ensemble ed., Roma, 2014

[53] Brathwaite, Carpentíer, Glissand, Walcott (edited and translated by Andrea Gazzoni), Pensiero caraibico, Ensemble ed., Roma, 2016, series Transculturazione

[54] G. Hajdari, San Pedro Cutud. Viaggio nell'inferno del tropico, Fara, 2004

[55] G. Hajdari, Muzungu. Diario in nero, Besa, 2006

[56] G. HaJdari, Corpo presente, Besa, Lecce, 2011

[57] G. Agamben: Pulcinella ovvero divertimento per li regazzi in quattro scene, Nottetempo, Milano, 2015

[58] G. Benvenuti, Il romanzo neostorico italiano, Carocci ed, Roma, 2012

editore of Isernia.

Andrea Gazzoni's reflection is also linked to the postcolonial Caribbean thought. After Kamau Brathwaite's translation (Diritti di passaggio,

Ensemble, 2014) he recently edited the volume Pensiero caraibico (Ensemble, Roma, 2017), released within Armando Gnisci's series. Tanks to him some important essays by Brathwaite, Carpentíer, Glissand and Walcott are now available in Italy.

As regard to the dissertation on World Literature in Italy, it's necessary to mention Rossana Morace's volume, Letteratura-Mondo italiana, Modernità Letteraria, Ets ed., Pisa, 2012

${ }^{v i}$ Ethnic group from the Albanian Alps. Their life was governed by the devotion to the Kanûn: oral regulatory code.

vii G. Abad's anthology, released by the publishing company Ensemble, is actually a florilegium from the wider compendium: In Ordinary time: Poems, Parables, Poetics (Quezon City, U. P. Press, 2004)

viii Malsor were the inhabitants of the Albanian Northern Alps; their isolation allowed the regulation of the society on Kanûn oral code, up until the beginning of the XIX century.

ix Besa means one's given word, one's sworn word. 